\title{
The Impact of Stock Market Development on Economic Growth: The Case of Botswana
}

\author{
Ishmael Radikoko $^{1}$, Shadreck A. Mutobo ${ }^{2}$ \& Mphoeng Mphoeng ${ }^{1}$ \\ ${ }^{1}$ Faculty of Business, University of Botswana, Gaborone, Botswana \\ ${ }^{2}$ Research Assistant, University of Botswana, Gaborone, Botswana \\ Correspondence: Ishmael Radikoko, Faculty of Business, University of Botswana, Gaborone, Botswana. Tel: \\ 267-7184-0559. E-mail: radikokoi@ub.ac.bw
}

Received: November 2, 2019

Accepted: November 29, 2019

Online Published: November 30, 2019

doi:10.5539/ijef.v11n12p149

URL: https://doi.org/10.5539/ijef.v11n12p149

\begin{abstract}
This study examines the impacts of the stock market development on economic growth using Botswana as a case study. The study uses times series data covering a decade from 2006 to 2016 . The method of analysis used is the Auto regressive distributed lag (ARDL) bounds model. The stock market capitalization ratio (MCR) was used as a proxy for market size while value of shares traded ratio (ST) and Turnover ratio (TR) were used as a proxy for liquidity, collectively representing stock market development. Real gross domestic product (GDP) growth rate was used to represent economic growth .The results show that market capitalization and turnover ratio have a negative correlation with economic growth, while the value of shares traded has a strong positive correlation with economic growth. This result implies that liquidity has propensity to stimulate economic growth in Botswana. The results of this study also found that there exists no causality relationship between stock market development and economic growth. The government should make policies that boost the interest of domestic investors in Botswana as this might spur investors' interest and boost stock market activity which will improve liquidity and therefore stimulate economic growth.
\end{abstract}

Keywords: Botswana, stock market, economic growth, Auto Regressive Distributed Lag Bounds model

\section{Introduction}

The stock market has become one of the important ingredients of firms' expansion and in turn economic growth. The concept of financial development to promote economic growth was introduced by (Bagehot, 1873) and (Schumpeter, 1911). Schumpeter (1911) proposed that a developed and well organized financial system can contribute to the economic growth of a country. Stock markets serve as a veritable tool in mobilizing and allocating savings among competing uses which are critical to the growth and efficiency of the economy. The efficiency of the stock market performs an allocative functions of capital; allocating savings to firms with relatively high prospects as indicated by their rate of returns and level of risk.

Financial intermediation assembles household and foreign savings for investment process by firms. For sustainable growth and development, Funds must be effectively mobilized and allocated to enable business and the economy to harness their human, material and management resources for optimal output.

The Botswana Stock Exchange is Botswana's national stock exchange given the responsibility to operate and regulate the equities and fixed interests of security markets. Formally established in 1989, The BSE continues to be pivotal to Botswana's financial system, and in particular the capital market, as an avenue on which government, quasi-government and the private sector can raise debt and equity capital.

Numerous debates have directed whether stock market development has led to economic growth. The question is an important one in order to clear policy implications for countries that have financial sectors that are comparatively underdeveloped. Developed economies had explored both channels through which resources mobilization affects economic growth and development - money and capital market (Demirguc-kunt \& Levine, 1996). This is however, not the case in developing economies like Botswana, where emphasis is placed on money market with little consideration for capital market. The debate and arguments on the exact role of the Capital markets on economic growth is ongoing and so far, a number of studies have shown conflicting results. While some are of the opinion that a negative link exists between capital markets and economic growth, others 
argue that there exists a positive link.

This topic is of particular interest because of the importance attributed to the stock market in any country's economy. The findings of such a study should be of interest amongst the policy the BSE, investors and market participants as well as to potentially influence the Government's policy towards the development of financial markets in Botswana.

The rest of the paper is arranged as follows; next we look at the literature review follow by methodology, then findings and discussion and ending with concluding remarks and recommendations.

\section{Review of Related Literature}

The relationship between financial stock market and economic growth has become the field of research more and more explored. A number of studies in 'economics literature' have established a positive relationship between economic growth and stock market development. As cited by (Mishkin, 2001; Caporale, Howells, \& Soliman, 2004) state that a well-organized and managed stock market arouses investment opportunities in the country by recognizing and financing productive projects that eventually lead to economic activity, allocates capital efficiently, mobilizes domestic savings, helps diversifying risks and facilitates exchange of goods and services.

One line of research argues that the financial system is unimportant for economic growth; another line stresses the importance of the financial system in mobilizing savings, allocating capital, exerting corporate control, and easing risk management. Mayer (1988) argues that even large stock markets are unimportant sources of corporate finance. Stiglitz $(1985,1994)$ in addition to these arguments claims that stock market liquidity will not enhance incentives for acquiring information about firms. To add on to the negative effects the analysis of Shleifer and Summers (1988) further suggest that stock market development can hurt economic growth by easing counterproductive corporate takeovers. Levine and Zervos (1996) however differ from the claims raised by Shleifer and Summers (1988). In their research on the relationship between the stock market development and economic growth they provided empirical evidence on the major theoretical debates about the relationship between stock markets and long run economic growth using data on 41 countries from 1976 to 1993. Their results showed that stock market liquidity is positively and significantly correlated to current and future rates of economic growth, capital accumulation and productivity improvements even after controlling for economic, political and other factors. Azam et al. (2016) also studied stock market development and economic growth from 4 Asian countries during the period of 1991 to 2012 using ARDL bound testing approach. Their results showed that stock market development and foreign direct investment inflows play an important function in the process of economic growth and development in these selected countries. In addition their results indicated a long-term co-integration relationship between economic growth, foreign direct investment, Stock market development and inflation.

Omoruyi and Osaretin (2015) have also conducted a study on the stock market development and economic growth in Nigeria; an empirical assessment in which they used the unit root test, co-integration, an error correction mechanism and Granger causality from 1980 to 2011. Stock market development measures employed in this study were the market capitalization, turnover ratio, total value of shares traded, share index while real gross domestic product was used to measure economic growth. The results of the study showed that turnover ratio positively and significantly boosts economic growth both in the long run and in the short run while total value of shares traded and all share indexes were only positively significant in the short run. Adjasi and Biekpe (2006) studied the effect of stock market development on economic growth for 14 African countries in a dynamic panel modelling setting. The results of their study largely showed a positive relationship between stock market development and economic growth. The study further revealed that a positive influence of stock market development on economic growth is significant for upper 5 middle class countries and stock markets developments played a significant role in growth only for moderately capitalized markets.

Ruwaydah and Ushad (2015) empirically studied the effects of stock market development on economic growth in nine SADC countries using three stock market measures being market capitalization, the value of shares traded and turnover ratio and controlled for a number of variables that had an effect on economic growth. The study also empirically examined the macroeconomic elements on stock market development, the random effects approach within a pooled data framework. The first model results showed that stock market development is positively correlated with economic growth while the second model results revealed that all elements of stock market development are insignificant. Kadenge and Tafirei (2014) studied the short and long run impact of bank and stock market developments on growth in Zimbabwe for the period 1988 to 2012. The researcherss make use of a financially augmented production growth function, the ARDL approach and the error correction mechanism. Stock market development was found to have a negative impact on growth in the long run. A positive impact was 
found for the short run. For South Africa, Nyasha and Odhiambo (2014) failed to find any short-run and long-run relationship between market-based financial development and economic growth. However, they find a positive relationship between banks based financial development and economic growth. Consequently, given the above literature discussion, one can conclude that the impact of stock market development on economic growth is not definite as it differs from country to country.

Based on the above objectives, the researchers has assumed the following hypotheses:

H1. Stock market development has positive effects on Botswana's economic growth.

$\mathrm{H} 2$. There is a unidirectional relationship between stock market development and economic growth in Botswana.

\section{Data and Methodology}

The period covered for this research was ten years from 2006-2016. Data on Economic indicators such as GDP was collected from Statistics Botswana whiles data on Market Capilisation, Turnover and Value of shares traded was collected form Botswana Stock Exchange and all data collected was in the form of quarterly statistic.

All the variables used in this study were log-linearized. We used three indicators to measure stock market development, namely, the market capitalization ratio (MC), Total value of shares traded (ST) ratio and the turnover ratio (TR). Market capitalization together with the value of shares traded measures market size, while turnover measures liquidity (Muresan \& Silaghi, 2012). The real GDP growth rate measures economic growth in logarithm form (LGDP).

The ADRL representation of the co-integration test equation to be tested is therefore expressed as:

$$
\begin{aligned}
\Delta L G D P_{\mathrm{t}}=\propto_{0}+\sum_{i=0}^{n} & \propto_{1 \mathrm{i}} \Delta L M C_{\mathrm{t}-1}+\sum_{i=0}^{n} \propto_{2 \mathrm{i}} \Delta L T R_{\mathrm{t}-\mathrm{I}}+\sum_{i=0}^{n} \propto_{3 \mathrm{i}} \Delta L S T_{\mathrm{t}-\mathrm{i}}+\sum_{i=0}^{n} \propto_{4 \mathrm{i}} \Delta L G D P_{\mathrm{t}-\mathrm{i}} \\
& +\sigma_{1} L T M C_{\mathrm{t}-1}+\sigma_{2} L T R_{\mathrm{t}-1}+\sigma_{3} L S T_{\mathrm{t}-1}+\sigma_{4} L G D P_{\mathrm{t}-1}+\mu_{1 \mathrm{t}}
\end{aligned}
$$

Where all variables are as defined above, $\Delta$ is the difference operator, $\propto_{0}$ is a constant, $\sum_{1}, \propto_{\mathrm{i1} 1} \propto_{\mathrm{i} 4}$ and $\sigma_{\mathrm{ilto}} \sigma_{\mathrm{i} 4}$ are the respective coefficients and $\mu_{1 \mathrm{t}}$ is the error term. The coefficients show how strongly the regressor influences economic growth respectively. The ADRL estimation involves testing the null hypothesis of no co-integration relationship against the alternative hypothesis of the existence of a co-integration relationship. The null and alternate hypotheses were therefore stated as

$$
H_{0}: \sigma_{1}=\sigma_{2}=\sigma_{3}=\sigma_{4}=0 \quad H_{1}: \sigma_{1} \neq \sigma_{2} \neq \sigma_{3} \neq \sigma_{4} \neq 0
$$

Unorganized data collected on macro-economic indicators was organized into tabular form to represent time series of events or activities of the stock market. To examine the impact of stock market development on the economy, data on macro-economic indicators where graphically presented to depict the impact graphically. Statistical computations were carried out using Microsoft Excel and Eviews Software, and any existing correlations or relationships were highlighted accordingly..

\section{Results}

\subsection{Statistical Description}

Statistical description of the data is shown in Table 1 below. It embodies presentation of the means, skewness, kurtosis, Jarque-Bera statistics and associated p-values of the respective variables.

Table 1. Descriptive statistics

\begin{tabular}{lllll}
\hline & RGDP & MC & LTR & LST \\
\hline Observations & 44 & 44 & 44 & 44 \\
Mean & 4.80682 & 1.86603 & -4.7239 & -4.113991 \\
Median & 6 & 1.89656 & -4.7372 & -4.027629 \\
Max & 13.4 & 2.40153 & -3.4162 & -2.93124 \\
Min & -10.4 & 1.04237 & -5.7124 & -5.489382 \\
Std. Dev. & 5.65983 & 0.29878 & 0.51854 & 0.611707 \\
Skewness & -0.9784 & -0.5122 & 0.13704 & -0.170237 \\
Kurtosis & 3.69733 & 3.31969 & 2.46021 & 2.454692 \\
Jarque-Bera & 7.91188 & 2.11145 & 0.67191 & 0.757687 \\
probability & 0.01914 & 0.34794 & 0.71465 & 0.684653 \\
\hline
\end{tabular}

The results in the above data set, reveal that the distributional property of the data is normal for MC, LTR, and LST series, and non-normal for RGDP. Variables with non-normal distribution in their raw form where $\log$ 
linearized but RGDP was still non-normal even after Log linearization. In statistics in order for series to be observed as following a normal distribution, it should have a skewness value of Zero and a kurtosis value of about three in a Gaussian distribution. The RGDP, MC, LTR and LST report skewness values of -0.978431 , $-0.512226,0.137039$, and -0.170237 respectively and kurtosis values of 3.697326, 3.319689, 2.460205 and 2.454692 respectively. These results suggest that three data series MC, LTR and LST follow normal distribution and RGDP follows non-normal distribution.

\subsection{Test for Stationarity}

In order to avoid the problem of spurious regression results, the researchers examined the time series properties of the variables employed in the research work. Including a non-stationary variable in a model could lead to spurious regression co-efficient estimates (Granger \& Newbold, 1977). Therefore to determine if the variables are stationary or not and also to ascertain the order(s) of integration of the variables, the Augmented Dickey Fuller (ADF) unit root test was employed. The researchers used this method because it is the most common unit root test used, and unlike the Phillips Perron test and KPSS test, the regression run includes lagged values of the first differences.

Null hypothesis: Series has a unit root.

Alternative hypothesis: Series has no unit root.

The decision rule stated that if $t$-statistic $>A D F$ critical value $=>$ reject null hypothesis i.e. no unit root exists and if t-statistic < $\mathrm{ADF}$ critical value $\Rightarrow>$ fail to reject null hypothesis i.e. unit root exists. In all cases the interpretation of the unit root test results was based on absolute values. The Augmented Dickey Fuller (ADF) value was compared with the critical value at $5 \%$ level of significance in order to determine the corresponding order of integration.

Table 2. Results of the Augmented Dickey-Fuller test

\begin{tabular}{lcccccc}
\hline \multirow{2}{*}{ Remarks } & \multirow{2}{*}{ series } & \multicolumn{2}{c}{ ADF STATISTIC } & \multicolumn{2}{c}{ Critical Values } & \multicolumn{2}{c}{ ORDER OF } \\
\cline { 2 - 5 } & & LEVELS & $\mathbf{1}^{\text {ST }}$ DIFF & $\mathbf{1 \%}$ & $\mathbf{5 \%}$ & INTEGRATION \\
\hline STATIONARY & RGDP & -3.14501 & -5.46382 & -4.211868 & -3.5298 & I $(1)$ \\
STATIONARY & MC & -2.84413 & -5.58133 & -4.192337 & -3.5208 & I $(1)$ \\
STATIONARY & LTR & -7.40653 & -14.2857 & -4.186481 & -3.5181 & I $(0)$ \\
STATIONARY & LST & -6.32569 & -13.8432 & -4.186481 & -3.5181 & I $(0)$ \\
\hline
\end{tabular}

The results of the ADF test are presented in table 2 above.

The result in table 2 above reveals that LTR and LST variables were stationary at levels i.e. unit root does not exist in the series at Levels. However RGDP and MC achieved stationarity after they had been differenced once i.e. unit root exists at Levels but does not, at first difference. The economic implication of non-stationary time series is that of a persistent shock if there is a disturbance on such a variable. The result shows that the variables are able to withstand shock to a good extent and unit root test also reveals that all the variables are integrated of order $\mathrm{I}(0)$ and $\mathrm{I}(1)$. This property exhibited by the series created a necessary condition for the development of the ARDL model also called the Bounds test.

\subsection{Lag Length Selection}

The first step in developing the Bounds test is the selection of the appropriate lag for the model. The selection of lag length has significant implications in estimating the ARDL model. Hall (1990) emphasizes the significance of choosing an appropriate lag arguing that a lag order that is too low will lead to problems with serial correlation whilst a too high one could potentially lead to small sample problems. The researchers used unrestricted VAR model by taking different lags (a maximum of eight) to choose the optimal lag for the model. The lag order selection was based on the number of lags that minimize the Akaike Information Criterion (AIC). As such, according to the results of the VAR estimation as shown by the table 3 below, the study will base the model on the selected lag length of 4 . 
Table 3. VAR lag order selection criteria results

\begin{tabular}{ccccccc}
\hline Lag & LogL & LR & FPE & AIC & SC & HQ \\
\hline 0 & -104.7228 & NA & 29.24940 & 6.212733 & $6.390487^{*}$ & 6.274094 \\
1 & -104.6014 & 0.208157 & 30.78502 & 6.262937 & 6.485130 & 6.339638 \\
2 & -104.6013 & 0.000127 & 32.64259 & 6.320076 & 6.586707 & 6.412117 \\
3 & -104.5935 & 0.012586 & 34.61743 & 6.376769 & 6.687839 & 6.484150 \\
4 & -98.08216 & $10.04601^{*}$ & $25.33486^{*}$ & $6.061838^{*}$ & 6.417346 & $6.184559^{*}$ \\
5 & -97.68092 & 0.596127 & 26.31089 & 6.096053 & 6.495999 & 6.234114 \\
6 & -97.67568 & 0.007489 & 27.97684 & 6.152896 & 6.597281 & 6.306298 \\
7 & -96.99793 & 0.929487 & 28.65848 & 6.171310 & 6.660134 & 6.340052 \\
8 & -95.70255 & 1.702500 & 28.37457 & 6.154431 & 6.687694 & 6.338513 \\
\hline
\end{tabular}

Table 4. Estimation of the ARDL equation

\begin{tabular}{|c|c|c|c|c|}
\hline Variable & Coefficient & Std. Error & t-Statistic & Prob.* \\
\hline GDP(-1) & 0.382912 & 0.16081 & 2.3811 & 0.0246 \\
\hline $\operatorname{GDP}(-2)$ & 0.005894 & 0.18508 & 0.03184 & 0.9748 \\
\hline $\operatorname{GDP}(-3)$ & 0.201001 & 0.18505 & 1.0862 & 0.287 \\
\hline $\operatorname{GDP}(-4)$ & -0.340266 & 0.15116 & -2.251 & 0.0327 \\
\hline LST & 241.4279 & 92.2525 & 2.61704 & 0.0144 \\
\hline $\operatorname{LST}(-1)$ & 22.77962 & 13.0031 & 1.75186 & 0.0911 \\
\hline $\operatorname{LST}(-2)$ & -17.84138 & 9.00073 & -1.9822 & 0.0577 \\
\hline LTR & -238.7769 & 91.9299 & -2.5974 & 0.015 \\
\hline $\operatorname{LTR}(-1)$ & -22.56838 & 12.5735 & -1.7949 & 0.0839 \\
\hline $\operatorname{LTR}(-2)$ & 14.66159 & 8.99833 & 1.62937 & 0.1148 \\
\hline $\operatorname{LTR}(-3)$ & -3.108612 & 1.58334 & -1.9633 & 0.06 \\
\hline $\mathrm{MC}$ & -125.7025 & 49.0175 & -2.5644 & 0.0162 \\
\hline $\mathrm{C}$ & 69.45075 & 38.314 & 1.81267 & 0.081 \\
\hline R-squared & 0.676557 & \multicolumn{2}{|c|}{ Mean dependent var } & 4.435 \\
\hline Adjusted R-squared & 0.532804 & \multicolumn{2}{|c|}{ S.D. dependent var } & 5.71142 \\
\hline S.E. of regression & 3.903853 & \multicolumn{2}{|c|}{ Akaike info criterion } & 5.81876 \\
\hline Sum squared resid & 411.4818 & \multicolumn{2}{|c|}{ Schwarz criterion } & 6.36765 \\
\hline Log likelihood & -103.3752 & \multicolumn{2}{|c|}{ Hannan-Quinn criter. } & 6.01722 \\
\hline F-statistic & 4.706394 & \multicolumn{2}{|c|}{ Durbin-Watson stat } & 1.83075 \\
\hline Prob(F-statistic) & 0.000406 & & & \\
\hline
\end{tabular}

Table 4 above displays the results of the estimated Selected model (ARDL 4, 2, 3, 0) with maximum number of lags of 4 using Akaike info criterion(AIC).

\subsection{Residual Diagnostics}

\subsubsection{Heteroscedasticity}

The researchers used the Breusch-Pagon-Godfrey test of heteroscedasticity to check if the ARDL model is correctly specified such that error terms are independent from the regressors which are essentially lagged values of the dependent variables (MC, LST, and LTR). However the test is employed to check if the variance of the error terms is constant (homogenous variance). The researchers therefore tested the null hypothesis of homoscedasticity against the null of heteroscedasticity.

Table 5. Heteroskedasticity test: Breusch-Pagan-Godfrey results

\begin{tabular}{lrlr}
\hline F-statistic & 0.929743 & Prob. F(12,27) & 0.5328 \\
Obs*R-squared & 11.69582 & Prob. Chi-Square(12) & 0.4704 \\
Scaled explained SS & 7.59019 & Prob. Chi-Square(12) & 0.8163 \\
\hline
\end{tabular}

According to the results presented above in table 5, the probability Chi-Square value is more than $5 \%$ which therefore means null hypothesis is accepted dictating that there is no heteroscedasticity in the residuals.

\subsubsection{Serial Correlation}

The estimated model was then tested for serial correlation and whether it is stable or not. The Breusch-Godfrey 
Serial Correlation LM Test was performed to test for serial correlation.

Null hypothesis: model has no serial correlation

Alternative hypothesis: model has serial correlation.

\section{Decision Rule}

If Probability Chi-Square value $>5 \%=>$ Accept null hypothesis i.e. model has no serial correlation

If Probability Chi-Square value $<5 \% \Rightarrow$ reject null hypothesis i.e. the model has serial correlation. The results of this test are presented in table 4 below.

Table 6. Breusch-Godfrey Serial Correlation LM Test

\begin{tabular}{lr}
\hline F-statistic & 0.2993 \\
Obs*R-squared & 3.07234 \\
Prob. F(4,14) & 0.8735 \\
Prob. Chi-Square(4) & 0.5458 \\
\hline
\end{tabular}

From the results it can be clearly noted that the Probability Chi-square of the 4 lag model is $54.5 \%$ which is greater than $5 \%$ therefore we fail to reject the null hypothesis suggesting that there is no serial correlation in residuals.

\subsection{Cu sum (Cumulative Sum of Recursive Residuals) Test}

Brown et.al (1975) introduced cusum (cumulative sum) and Cusum of squares tests. Cusum test is based on a plot of the sum of recursive residual. The Following chart shows two straight red lines, while there is one blue line which is within these two lines. The red lines represent 5\% critical bounds, where null hypothesis of having stable parameters for each of the projected variables is rejected if the blue line crosses the red line. On the other hand if the plot remains within the two straight lines the null hypothesis is not rejected. Cumulative sum test helps to show if coefficients of regression are changing systematically, whereas cumulative sum of square test is helpful to showing if the coefficients of regression are changing suddenly (Bhatti,Al-Shanfari et al, 2006). The researchers performed the Cusum test and the results are presented below.

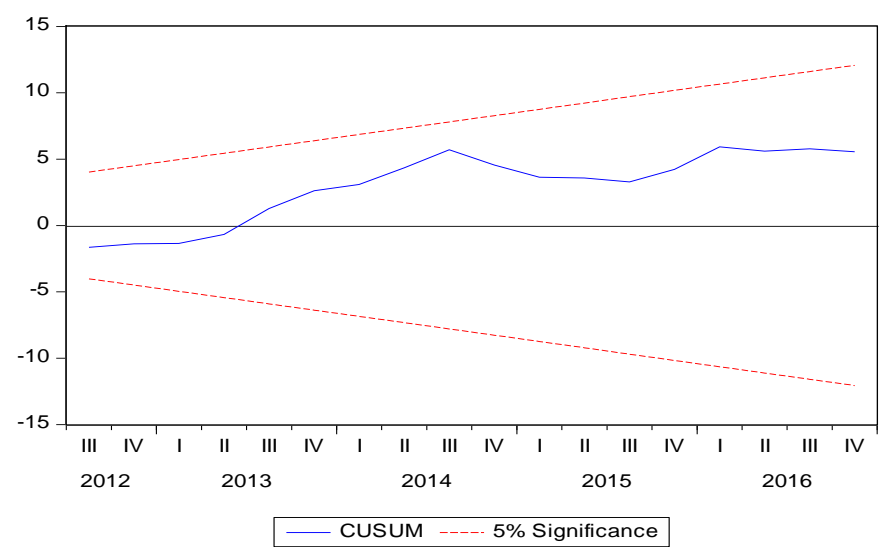

Figure 1. $\mathrm{Cu}$ sum test result

Based on the chart representation in figure 1 above of the CUSUM test, the researchers concluded that there is no structure break or simply that parameters are stable because the blue line is existing within the red straight lines hence failing to reject the null hypothesis of stable parameters. After establishing that the model had no serial correlation and that it was stable, the researchers was now able to proceed to carry out the bounds test to determine co-integration between the variables and whether there exists a long run relationship between the variables.

\subsection{Bounds Test}

The bounds testing procedure is based on the joint F-statistic or Wald statistic that tests the null hypothesis of no co-integration. Pesaran et al. (2001) and Narayan (2005) individually report two sets of critical values for a given significance level. One set of critical values assumes that all variables included in the ARDL model are I(0), 
while the other is calculated on the assumption that the variables are I(1). If the computed test statistic exceeds the upper critical bounds value, then the null hypothesis is rejected. If the F-statistic falls into the bounds then the cointegration test becomes inconclusive. In this case, following Kremers et al. (1992) and Banerjee et al. (1998), the error correction term will be a useful way for establishing cointegration. If the F-statistic is lower than the lower bounds value, then the null hypothesis of no cointegration cannot be rejected.

Table 7. Bounds test result

\begin{tabular}{lcl}
\hline Test Statistic & Value & $\mathrm{k}$ \\
F-statistic & 4.997423 & 3 \\
\hline \multicolumn{3}{c}{ Critical Value Bounds } \\
\hline Significance & I0 Bound & I1 Bound \\
\hline $10 \%$ & 2.72 & 3.77 \\
$5 \%$ & 3.23 & 4.35 \\
$2.50 \%$ & 3.69 & 4.89 \\
$1 \%$ & 4.29 & 5.61 \\
\hline
\end{tabular}

The cointegration test under the bounds testing approach involves comparing the F-statistics against critical values. The calculated F-statistics, together with the critical values, are reported in Table 7 above. The calculated F-statistic F (gdp /mc ltr lst) $=4.997423$ exceeds the upper critical bound level at 10\%, 2.5\% and 5\% significance. This means that the null hypothesis should be rejected, which therefore means that there is cointegration between the variables. It can be concluded based on this finding that there exists a long run relationship between the variables.

\subsection{Long and Short Run Elasticities}

The researchers carried out the ARDL Cointergration and Long run form test to determine the long run and short run coefficients and the results are presented below. The long-run results are reported in the table 8 below. All estimated coefficients are statistically significant and have correct signs as expected.

Table 8. Long run coefficients

\begin{tabular}{lcccc}
\hline Variable & Coefficient & Std. Error & t-Statistic & Prob. \\
\hline MC & -167.50069 & 68.54084 & -2.44381 & 0.0213 \\
LST & 328.287103 & 132.0165 & 2.486714 & 0.0194 \\
LTR & -332.8524 & 131.98192 & -2.52196 & 0.0179 \\
C & 92.544297 & 51.40767 & 1.800204 & 0.083 \\
\hline
\end{tabular}

Findings confirmed that there is a negative and significant relationship between mc and gdp at $5 \%$ level of significance. This implies that a $1 \%$ increase in MC variable in this response there will be a decrease of 167.5 units in the dependent variable. On the other hand there is a positive and significant relationship between LST and the dependent variable gdp at 5\% level of significance.it employs that an increase of $1 \%$ in variable LST will lead to an increase in the dependent variable of about 328.3 units. There is also a negative but significant relationship between the variables LTR and GDP at 5\% significance level. Increase in variable LTR by $1 \%$ will lead to a decrease in the dependent variable by 332.9 units.

Table 9. Short run results

\begin{tabular}{ccccc}
\hline Variable & Coefficient & Std. Error & t-Statistic & Prob. \\
\hline D(GDP(-1)) & 0.13337 & 0.15568 & 0.8567 & 0.3991 \\
D(GDP(-2)) & 0.13927 & 0.15748 & 0.88435 & 0.3843 \\
D(GDP(-3)) & 0.34027 & 0.15116 & 2.251 & 0.0327 \\
D(MC) & -125.7 & 49.0175 & -2.5644 & 0.0162 \\
D(LST) & 241.428 & 92.2524 & 2.61704 & 0.0144 \\
D(LST(-1)) & 17.8414 & 9.00073 & 1.98221 & 0.0577 \\
D(LTR) & -238.78 & 91.9299 & -2.5974 & 0.015 \\
D(LTR(-1)) & -14.662 & 8.99833 & -1.6294 & 0.1148 \\
D(LTR(-2)) & 3.10861 & 1.58334 & 1.96332 & 0.06 \\
CointEq(-1)ECT & -0.7505 & 0.15926 & -4.7123 & 0.0001 \\
\hline
\end{tabular}

The table above shows the sort run coefficients, but of vital importance is the error correction term. The error 
correction term (-0.750459) here is negative and significant meaning that there is a long run causality running from independent variables to dependent variable. It also confirms that all the variables are cointegrated or have long run relationship. We can also say that about 75percent gap between long run equilibrium value and the actual value of the dependent variable (GDP) has been corrected. It can be also said that speed of adjustment towards long run equilibrium is 75 percent quarterly. Also we can say that the system corrects its previous period disequilibrium at a speed of 75 percent quarterly.

\subsection{Granger Causality Test}

Granger causality aims to establish if there is a presence of correlation between the value of one variable and the lagged values of the other variables in the system, hence show that the lagged values of a variable provide a statistically valuable information to predict another variable. The Granger causality tests can additionally be used to check if a particular variable can be treated as exogenous (i.e. not affected by any variables in the model). Granger causality tests however can generate results that are misleading especially when the relationship involves two or more variables. This happens if both the first and second variables are driven by past values of the third variable. Since Granger causality test do not indicate the sign of the relationships between variables and the length of time of the effect, they can be supplemented with the use of impulse responses and variance decompositions for further analysis of the relations. According to Mittnik and Semmler (2013) Granger causality should be regarded as a descriptive tool that summarizes correlational and linearly approximated relationships. The researchers performed the Granger causality test on the data. The purpose of this test was to determine whether economic growth caused stock market development or whether the Stock market development caused economic growth.

Null Hypothesis: economic growth (gdp) does not granger cause stock market development (mc, lst, ltr) and vice versa.

Alternative Hypothesis: economic growth (gdp) granger causes stock market development (mc,lst,ltr) and vice versa.

In order to test the null hypothesis the researchers appointed F-statistic. The guideline is that if the P-value is more than 5\% we cannot reject null hypothesis but rather we accept null hypothesis. And if the P-value is less than 5\% we reject null hypothesis meaning that we accept alternative hypothesis.

From the findings as shown in in table 10 below, the researchers concluded that there is no granger causality relationship existing between the variables of Stock market development and economic growth. All the paired variables have a probability value greater than $5 \%$ therefore leading to the decision to accept Null hypothesis, meaning that one variable does not granger cause the other variable in any case. It can be concluded that the coefficients of the independent variables (MC, ST and TR) are all equal to zero and as such offer no other information on predicting the future of the dependent variable (GDP). Policy makers will not be able to use these findings to show that in order to accelerate growth of the economy they could develop the stock market even further. However there are some theoretical issues with the direct Granger causality test. The first issue is that the test assumes the correct specification to be unknown, which is a direct violation of the correct specification assumption of Ordinary least Squares. The other issue among others is that this test relies on overfitting the model to make sure that all the auto dependence processes are removed from the data, which in turn reduces the predictive power of the test and causes estimator inefficiency. The final major issue of this test is that of its dependence on the right choice of conditioning set and its sensitivity to data included. (Granger, 1969).

Table 10. Results of Granger Causality Test

\begin{tabular}{cllll}
\hline Direction of causality & p-value & lags & Decision & outcome \\
\hline mc $>$ gdp & 23.5 & 4 & Do not reject Null hypothesis & Mc does not granger cause gdp \\
Gdp $>$ mc & 69.39 & 4 & Do not reject Null hypothesis & gdp does not granger cause mc \\
Lst $>$ gdp & 17.46 & 4 & Do not reject Null hypothesis & lst does not granger cause gdp \\
Gdp $>$ lst & 59.61 & 4 & Do not reject Null hypothesis & gdp does not granger cause lst \\
Ltr>gdp & 41.09 & 4 & Do not reject Null hypothesis & ltr does not granger cause gdp \\
Gdp $>1 t r$ & 31.66 & 4 & Do not reject Null hypothesis & gdp does not granger cause ltr \\
Lst $>$ mc & 46.89 & 4 & Do not Reject Null hypothesis & Mc does not granger cause lst \\
mc $>1 s t$ & 42.77 & 4 & Do not reject Null hypothesis & Ltr does not granger causes mc \\
Ltr>mc & 49.96 & 4 & Do not Reject Null hypothesis & Mc does not granger cause ltr \\
mc $>1 t r$ & 31.31 & 4 & Do not reject Null hypothesis & ltr does not granger cause lst \\
Ltr $>1 s t$ & 45.74 & 4 & Do not reject Null hypothesis & lst does not granger cause ltr \\
Lst>ltr & 33.41 & 4 & Do not reject Null hypothesis &
\end{tabular}




\section{Discussion}

In analyzing the impact of stock market development on economic growth in Botswana, the study applied the Auto Regressive Distributed Lag Bounds model and the results and findings have been presented above. From table 7 it can be noted that there is existence of cointegration between the variables. This supports the work of Enisan and Olufisayo (2009) who suggest that the stock market development is cointegrated with economic growth. From table 8 the results unveiled that stock market development measures where all statistically significant at 5\% level of significance. The coefficient of the constant 92.544297 implies that holding market capitalization, turnover ratio and value of shares traded constant, the gross domestic product will increase by 92.544297 units. However the researchers found that the value of shares traded has a positive relationship with GDP growth while market capitalization and turnover ratio exhibits negative relationships. This supports the work of wang and Ajit (2013), who found that there exists a negative correlation between stock market development represented by total market capitalization and GDP growth, both in the long run and in the short run. It also agrees with the work of Aiguh (2013), who found that market capitalization ratio is negatively related to economic growth. However it disagrees with Ogunleye and Adeyemi (2015) who suggests that there is a positive relationship between market capitalization and economic growth. The average coefficient of the adjusted R-Squared reveals that $53.3 \%$ of variations in economic growth were explained by the stock market development therefore ONLY $46.7 \%$ changes in economic growth of Botswana were not explained by stock market development. This suggests that stock market development has significantly impacted on Botswana's economic growth. The researchers found that there exists no causality between the stock market development and economic growth. No indicators of the stock market development show a causal relationship with the dependent variable i.e. (real GDP growth).

\section{Conclusion}

In this paper, an empirical investigation of the impact of the stock market development on economic growth in Botswana during the period 2006Q1 to 2016Q4 has been done. Stock market development is divide into total market capitalization, Total turnover and stocks traded value. Economic growth is estimated using gross Domestic Product growth rate. Quarterly data was employed for all variables. The study employs the ARDL bounds testing method to evaluate the relationship between economic growth and stock market development. The result of this empirically study show the existence of long run relationship between stock market development and economic growth. The empirical study found that the value of shares traded is the major determinant of stock market indicators that promoted economic growth in Botswana, because there is a long positive relationship between stock market value of shares traded and real GDP growth, and at the same time the indicator is robust and statistically significant. There is however a negative relationship between Market capitalization and Turnover ratio with real GDP growth. The empirical study also found that no causal relationship exists between stock development and Economic growth.

\section{Recommendations}

Policy makers and opinion formers should gear efforts towards fine-tuning the indices that can result in long term pessimism in the stock market like unpaid dividend, delay in dividend payments and transfer of stocks. This is pertinent to encourage and cajole greater population of the income citizenry into investing in the stock market. This way, activities in a stock market will grow, capital accumulation increased and national productivity may be improved accordingly. Initiatives that educate the public about the importance of the stock market to the economy, and how participation by individuals in the stock market can improve the stock exchange and boost the economy should be encouraged. Such initiatives are already in place such as the fortune 500 .

\section{References}

Adjasi, C. B., \& Biekpe, N. B. (2006). Stock market development and economic growth: The case of selected

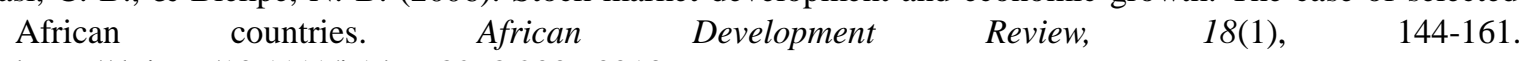
https://doi.org/10.1111/j.1467-8268.2006.00136.x

Alile, H. I. (1984). The Nigerian Stock Exchange: Historical perspective, operations and contributions to economic development. Central Bank of Nigeria Bullion, 11, 65-69.

Amadeo, K. (2018, March 3). The balance. Retrieved from https://www.thebalance.com/what-is-economic-growth-3306014

Azam, M., Muhammad, H., Samsi, A. B., \& Raji, J. O. (2016). Stock Market Development and Economic Growth: Evidences from Asia-4 Countries. International Journal of Economics and Financial Issues, 6(3), 1200-1208. 
Bagehot, W. (1873). A description of the money market. Lombard street: Scribner, Armstrong and Company.

Banerjee, A., Dolado, J., \& Mestre, R. (1998). Error-correction mechanism tests for cointegration in a single-equation framework. Journal of Time Series Analysis, 19(3), 267-283. https://doi.org/10.1111/1467-9892.00091

Bayar, Y., Kaya, A., \& Yildirim, M. (2014). Effects of stock market development on economic growth: Evidence from Turkey. International Journal of Financial Research, 5(1), 93. https://doi.org/10.5430/ijfr.v5n1p93

Bhatti, M. I., Al-Shanfari, H., \& Hossain, M. Z. (2006). Econometrics Analysis of Model Testing and Model Selection.

Botswana Stock Exchange. (2006). Botswana Stock Exchange Annual report. Botswana Stock Exchange:Gaborone.

Botswana Stock Exchange. (2007). Botswana Stock Exchange Annual report. Botswana Stock Exchange:Gaborone.

Botswana Stock Exchange. (2008). Botswana Stock Exchange Annual report. Botswana Stock Exchange:Gaborone.

Botswana Stock Exchange. (2009). Botswana Stock Exchange Annual report. Botswana Stock Exchange:Gaborone.

Botswana Stock Exchange. (2010). Botswana Stock Exchange Annual report. Botswana Stock Exchange:Gaborone.

Botswana Stock Exchange. (2011). Botswana Stock Exchange Annual report. Botswana Stock Exchange:Gaborone.

Botswana Stock Exchange. (2012). Botswana Stock Exchange Annual report. Annual report, Botswana Stock Exchange: Gaborone

Botswana Stock Exchange. (2013). Botswana Stock Exchange Annual report. Annual report, Botswana Stock Exchange: Gaborone.

Botswana Stock Exchange. (2014). Botswana Stock Exchange Annual report. Annual report, Botswana Stock Exchange:Gaborone.

Botswana Stock Exchange. (2015). Botswana Stock Exchange Annual report. Botswana Stock Exchange: Gaborone.

Botswana Stock Exchange. (2016). Botswana Stock Exchange Annual report. Botswana Stock Exchange: Gaborone.

Brooks, C. (2009). Introductory econometrics for finance (2nd ed.). Cambridge: Cambridge University Press.

Brown, R. L., Durbin, J., \& Evans, J. M. (1975). Techniques for testing the constancy of regression relationships over time. Journal of the Royal Statistical Society. Series B (Methodological), 149-192. https://doi.org/10.1111/j.2517-6161.1975.tb01532.x

Demirguc-kunt, A., \& Levine, R. (1996). stock market development and financial intermediaries: Stylized facts. The World Bank Econmic Review, 10(2), 291-321. https://doi.org/10.1093/wber/10.2.291

Enisan, A. A., \& Olufisayo, A. O. (2009). Stock market development and economic growth: Evidence from seven sub-Sahara African countries. Journals of Economics and Business, 61(2), 162-171. https://doi.org/10.1016/j.jeconbus.2008.05.001

Granger, C. W. (1969). Investigating causal relations by econometric models and cross-spectral methods. Econometrica: Journal of the Econometric Society, 424-438. http://dx.doi.org/10.2307/1912791

Granger, C. W., \& Newbold, P. (1977). Identification of two-way causal systems. In Frontiers of quantitative economics (Vol. 3). North-Holland Amsterdam.

Hall, A. (1990). Testing for a Unit Root in Time Series with Pretest Data-based Model Selection. North Carolina State University, Working Paper.

Kadenge, P. G., \& Tafirei, F. (2014). The impact of Bank and Stock Market Developments on Economic Growth in Zimbabwe: 1988 to 2012. BOJE; Botswana Journal of Economics, 12(2), 74-94.

Kremers, J. J., Ericsson, N. R., \& Dolado, J. J. (1992). The power of cointegration tests. Oxford Bulletin of Economics and Statistics, 54(3), 325-348. https://doi.org/10.1111/j.1468-0084.1992.tb00005.x 
Levine, R. (1996). stock market development and long-run growth. The World Bank Economic Review, 10(2), 323-339. https://doi.org/10.1093/wber/10.2.323

Mayer, C. (1988). new issues in corporate finance. European Economic Review, 32(5), 1167-1183. https://doi.org/10.1016/0014-2921(88)90077-3

Mittnik, S. \& Semmler, W. (2013). The real consequences of financial stress. Journal of Economic Dynamics and Control, 37(8), 1479-1499. https://doi.org/10.1016/j.jedc.2013.04.014

Muresan, D., \& Silaghi, M. L. P. (2013). Turnover and market value in capital markets in the European Union. Romanian Journal of Economics, 37(2), 80-90.

Narayan, P. K. (2005). The saving and investment nexus for China: Evidence from cointegration tests. Applied Economics, 37(17), 1979-1990. https://doi.org/10.1080/00036840500278103

Nazir, M. S., Gilan, M. M., \& Javed, U. (2010). relationship between economic growth and stock market development. African Journal of Business Management, 4(16), 3473-3479.

Nyasha, S., \& Odhiambo, N. M. (2015). The impact of banks and stock market development on economic growth in South Africa: An ARDL-bounds testing approach. Econstor, 9(1), 93-108. http://dx.doi.org/10.5709/ce.18979254.161

Ogunleye, E. O., \& Ademeyi, P. A. (2015). The impact of stock market development on economic growth in Nigeria. Journal of Economics and Sustainable Development, 6(23), 21-28.

Omoruyi, A., \& Osaretin, I. A. (2015). Stock market development and economic growth in Nigerian:an empirical assessment. International Journal of Business and Social Science, 6(1), 27-36.

Pesaran, M. H., Shin, Y., \& Smith, R. J. (2001). Bounds testing approaches to the analysis of level relationships. Journal of Applied Econometrics, 16(3), 289-326. https://doi.org/10.1002/jae.616

Ruwaydah., A., \& Ushad, S. A. (2015). Effects of stock market development on economic growth: The case of SADC countries. Third Middle East Conference on Global Business, Economic, Finance and Banking (pp. 1-20). Dubai.

Schumpeter, J. A. (1911). The Theory of Economic Development: An Inquiry into Profits, capital, credit, interest, and the business cycle. Cambridge, MA: Harvard University Press.

Shleifer, A., \& Summers, L. H. (1988). Breach of trust in hostile takeovers. In Corporate takeovers: Causes and consequences. Chicago: University of Chicago Press. https://doi.org/10.3386/w2342

Stiglitz, J. A. (1994). The role of the state in financial markets. In proceedings of the world bank. Annual conference on development economics 1993. washington, D.C: world bank.

Stiglitz, J. E. (1985). credit markets and control of capital. journal of Money, Credit and Banking, 17(2), 133-152. https://doi.org/10.2307/1992329

Teo, K. H., Ng, S. W., So, B. E., Tan, W. K., \& Yu, K. C. (2015). The determinants of Malaysian stock market performance (Doctoral dissertation, UTAR).

The Economic times. (n. d.). Retrieved on October 16, 2017 from https://economictimes.indiatimes.com/

Wang, B., \& Ajit, D. (2013). Stock market and economic growth in China. Economics Bulletin, 33(1), 95-103.

\section{Copyrights}

Copyright for this article is retained by the author(s), with first publication rights granted to the journal.

This is an open-access article distributed under the terms and conditions of the Creative Commons Attribution license (http://creativecommons.org/licenses/by/4.0/). 